\title{
Climate-Volcanism Feedback and the Toba Eruption of $\sim 74,000$ Years Ago
}

\author{
Michael R. RAmpino \\ Earth Systems Group, Department of Applied Science, New York University, New York, New York 10003; and NASA, Goddard Institute for \\ Space Studies, New York, New York 10025 \\ AND \\ STEPHEN SELF \\ Department of Geology and Geophysics, School of Ocean and Earth Science and Technology, University of Hawaii at Manoa, Honolulu, \\ Hawaii 96822
}

Received May 5, 1992

\begin{abstract}
A general feedback between volcanism and climate at times of transition in the Quaternary climate record is suggested, exemplified by events accompanying the Toba eruption $(\sim 74,000 \mathrm{yr}$ ago), the largest known late Quaternary explosive volcanic eruption. The Toba paroxysm occurred during the $\delta^{18} \mathrm{O}$ stage $5 \mathrm{a}-4$ transition, a period of rapid ice growth and falling global sea level, which may have been a factor in creating stresses that triggered the volcanic event. Toba is estimated to have produced between $10^{15}$ and $10^{16} \mathrm{~g}$ of fine ash and sulfur gases lofted in co-ignimbrite ash clouds to heights of at least $32 \pm 5 \mathrm{~km}$, which may have led to dense stratospheric dust and sulfuric acid aerosol clouds. These conditions could have created a brief, dramatic cooling or "volcanic winter," followed by estimated annual Northern Hemisphere surface-temperature decreases of $-3^{\circ}$ to $5^{\circ} \mathrm{C}$ caused by the longer-lived aerosols. Summer temperature decreases of $\geqslant 10^{\circ} \mathrm{C}$ at high northern latitudes, adjacent to regions already covered by snow and ice, might have increased snow cover and sea-ice extent, accelerating the global cooling already in progress. Evidence for such climate-volcanic feedback, following Milankovitch periodicities, is found at several climatic transitions. 1993 University of Washington.
\end{abstract}

\section{INTRODUCTION}

The largest explosive volcanic events are those that produce voluminous ignimbrites (extensive silicic pyroclastic flow deposits). The $\sim 74,000$-yr-old Toba eruption, which is represented by the Younger Toba Tuff (YTT) rhyolitic ignimbrite deposits of Sumatra, Indonesia, and a very widespread co-ignimbrite ashfall in the Indian Ocean, is one of the greatest known volcanic events in the geologic record (Ninokovich et al., 1978; Rose and Chesner, 1987; Chesner et al., 1991). Considerable volumes of fine ash and perhaps a significant volume of the released gases are dispersed by so-called co-ignimbrite (or "phoenix") ash clouds (Sparks and Walker, 1977; Dobran et al., 1992), which rise above collapsing eruption columns and the active pyroclastic flows. Recent quantitative models for co-ignimbrite clouds (Sparks et al., 1986; Carey et al., 1989; Woods and Wohletz, 1991) suggest that these clouds can be an effective means of injecting large volumes of volcanic volatiles and fine dust well into the stratosphere, with possible substantial short-term global climatic impact. It is notable that in several of the largest recent historic eruptions that have caused atmospheric perturbations, for instance, Tambora 1815, Krakatau 1883, and Pinatubo 1991, a significant amount of the material injected high into the atmosphere was in co-ignimbrite ash clouds.

The question of whether volcanic eruptions can contribute to long-term changes in climate, such as glaciation, has long been a subject of debate. The exceptional size of the Toba eruption (Fig. 1), and its occurrence at a time of well-documented global climatic change, makes it an important test case of the possible contribution of explosive volcanism to the inception of glaciation and to abrupt climatic transitions. In this paper, we summarize recent information relating to the Toba eruption and use these data to estimate the resulting major perturbation of the global atmosphere. Comparison of these data with proxy climate data, and recent climate model results, allows an assessment of the likelihood that the eruption was a contributing factor to the major transition from warm to cold climates in the last glacial cycle and suggests a possible general feedback coupling between eruptions and climatic change.

\section{THE TOBA ERUPTION AND ITS WIDESPREAD ASH DEPOSIT}

The Toba YTT ignimbrite has earlier been dated by the $\mathrm{K} / \mathrm{Ar}$ method at 73,500 \pm 3500 уг old (Ninkovich et al., 1978). New ${ }^{40} \mathrm{Ar} /{ }^{39} \mathrm{Ar}$ age determinations give 73,000 \pm $4000 \mathrm{yr}$ while new $\mathrm{K} / \mathrm{Ar}$ determinations give 75,000 \pm 


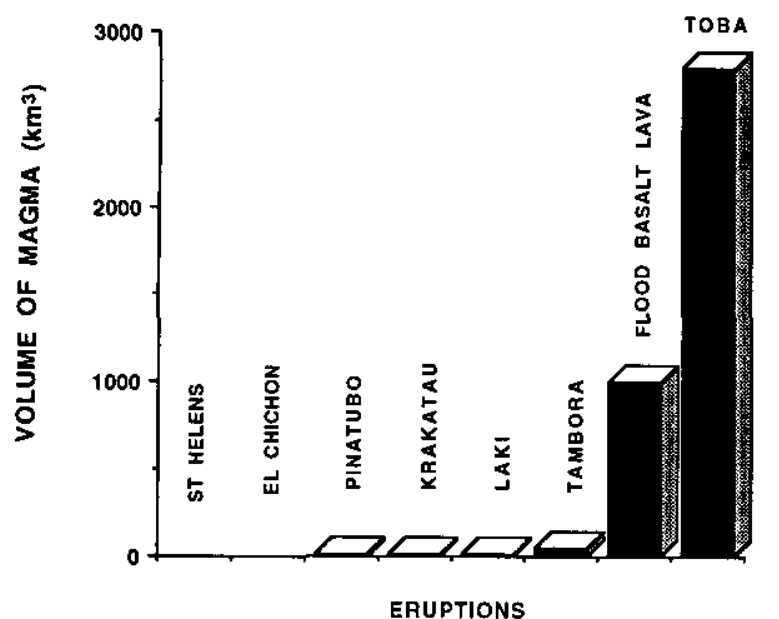

FIG. 1. Comparison of volumes of well-known historic eruptions and a typical flood basalt with the erupted volume of Toba. Note that at the scale shown, Mount St. Helens and El Chichón do not even show on the plot (various sources).

12,000 and $74,000 \pm 3000$ yr yielding a weighted mean age of 74,000 $\pm 2000 \mathrm{yr}$ (Chesner et al., 1991). The Toba ash layer occurs in deep-sea cores from the Indian Ocean coincident with the oxygen-isotope stage $5 \mathrm{a}-4$ transition (Dehn et al., 1991), estimated by SPECMAP (Martinson et al., 1987) methods to be $73,910 \pm 2590 \mathrm{yr}$ old (Fig. 2). It has also recently been identified and correlated over wide areas of the Indian subcontinent (Acharyya, 1993) and has been tentatively identified in Malaysia (see Chesner et al., 1991). The Toba eruption is so much larger than other known historic eruptions (Fig. 1) that the label supereruption may be appropriate (Rampino and Self, 1992).

The eruption apparently produced little or no plinian (sustained eruption column) fallout (Caress, 1985; Rose and Chesner, 1987) and all of the associated widespread fallout is thought to be co-ignimbrite ash. This ash blanket is $>12 \mathrm{~cm}$ thick in cores from the Bay of Bengal,

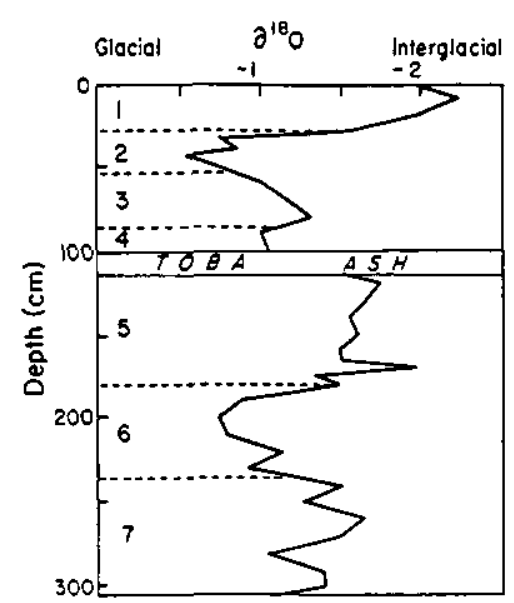

FIG. 2. Piston core RC14-37, Indian Ocean, showing position of the 15-cm-thick Toba co-ignimbrite ash layer at the oxygen-isotope stage 5a-4 boundary. Vertical scale is depth in core (Ninkovich et al., 1978). $\sim 1500 \mathrm{~km}$ from the volcano, and according to Rose and Chesner $(1987,1990)$ has a dense rock equivalent volume (DRE) of about $800 \mathrm{~km}^{3}$. Using the available ash thickness data, which are less than the original thicknesses due to erosion, to compute a likely minimum ash fall volume assuming an exponential decrease in thickness (Fierstein and Nathanson, 1992) yields values of between 475 and $1150 \mathrm{~km}^{3}$ bulk volume, depending on the slope of the exponential function, which is controlled by the most distal ash thicknesses. These amounts convert to about $310-750 \mathrm{~km}^{3}$ DRE, in general agreement with Rose and Chesner's estimate of a truly great ash fall volume. The ignimbrite deposits on Sumatra consist of a few thick flow units and have a volume of about $2000 \mathrm{~km}^{3}$ DRE. The estimated average crystal concentration in the ignimbrite (1.5 times; Caress, 1985) agrees well with the ratio of the volumes of co-ignimbrite ash fall to total ignimbrite.

The ignimbrite was emplaced by several massive and widespread but sluggish pyroclastic flows at temperatures of about $750^{\circ} \mathrm{C}$ (Rose and Chesner, 1990). Caress (1985) suggests that the bulk of the co-ignimbrite ash was generated above the collapsing eruption column, due to the lack of elutriation features in the ignimbrite, and this represents one possible scenario. However, even slowly moving pyroclastic flows generate significant coignimbrite ash clouds well away from the vent, as recently observed at Redoubt volcano in 1990 (Woods and Kienle, in press) and Mt. Pinatubo in 1991 (Koyaguchi and Tokuno, in press), and it is possible that much of the Toba ash cloud lifted off from the surface of the pyroclastic flows. Areas covered by individual flows are estimated to be on the order of $10^{5} \mathrm{~km}^{2}$, and each flow could have generated a large co-ignimbrite ash cloud. A measure of the duration of continuous fallout of Toba ash over the Indian Ocean suggests an eruption period of 2 weeks or less (Ledbetter and Sparks, 1979).

Analog experiments and theoretical models of the generation of co-ignimbrite ash clouds indicate that entrainment and heating of ambient air, and the sedimentation of ash particles, produce extremely vigorous convection above pyroclastic flows. Contraction of the convective cloud as it rises may lead to an increase in upward velocity (Woods and Wohletz, 1991; Sparks et al., 1986), and the buoyancy flux can carry the clouds to elevations in excess of $20 \mathrm{~km}$. Clouds will overshoot their neutral buoyancy height with subsequent momentum-driven rise well into the stratosphere. The top of the cloud then expands and spreads rapidly to produce the characteristic "umbrella" or "mushroom" shape. The optimum conditions for co-ignimbrite cloud rise into the stratosphere are likely to be met above moderate- to large-volume pyroclastic flows (tens to hundreds of $\mathrm{km}^{3}$ ), culminating in eruptions such as Toba.

The Toba eruption mass flux is estimated to have been $7-8 \times 10^{9} \mathrm{~kg} / \mathrm{sec}$ (Rose and Chesner, 1990; Woods and 
Wohletz, 1991), implying co-ignimbrite cloud heights of $32 \pm 5 \mathrm{~km}$, although the Woods and Wohletz model used an entrainment assumption more appropriate for a plinian column (Woods, 1988) than for an extremely wide coignimbrite column. Thus, the model underestimates the height for any eruption rate, and heights up to $40 \mathrm{~km}$ may be reasonable for mass eruption rates approaching $10^{10}$ $\mathrm{kg} / \mathrm{sec}$. If a significant proportion of the co-ignimbrite ash was lofted above the vent, as suggested by Caress (1985), a plinian model would be more appropriate to estimate the column height, which would also be in the order of 40 $\mathrm{km}$ (Woods and Wohletz, 1991). In summary, for all plausible cases, co-ignimbrite eruption cloud heights well above the tropical tropopause $(17 \mathrm{~km})$ are suggested for Toba.

\section{TOBA AEROSOLS AND CLIMATE}

Release of sulfur volatiles is especially important for the climatic impact of an eruption, as these form sulfuric acid aerosols in the stratosphere. By phase equilibria, Rose and Chesner (1990) estimated a water content for the YTT rhyolite of about $3 \mathrm{wt} \%$ and an $\mathrm{H}_{2} \mathrm{~S}$ content of $0.05 \mathrm{wt} \%$. Predicting that $\mathrm{H}_{2} \mathrm{~S}$ would have been the dominant sulfur phase in the Toba magma, they estimate that $3 \times 10^{15} \mathrm{~g}$ of $\mathrm{H}_{2} \mathrm{~S}$, equivalent to $\sim 1 \times 10^{16} \mathrm{~g}$ of $\mathrm{H}_{2} \mathrm{SO}_{4}$ aerosols, could have been released from the erupted magma (see also Chesner et al., 1991). Although the intrinsic sulfur content of rhyolite magmas is low, efficient degassing of the sulfur phase may be attained as it accompanies the water that exsolves from the melt. In the Toba case, the large volume of magma erupted is sufficient to give an enormous volatile release. Furthermore, it cannot be ruled out that a separate sulfur-volatile phase may have been present in the magma, as seems to be true in the case of Mt. Pinatubo (Westrich and Gerlach, 1992), which could make the above sulfur-emission estimate for Toba a minimum.

Physical and chemical processes in dense aerosol clouds may act in a "self-limiting" manner, significantly reducing the amount of long-lived $\mathrm{H}_{2} \mathrm{SO}_{4}$ aerosols (Rampino and Self, 1982). Using one-dimensional aerosol microphysical and photochemical models, Pinto et al. (1989) showed that for an aerosol cloud of $\sim 10^{14} \mathrm{~g}$ of $\mathrm{SO}_{2}$, condensation and coagulation are important in producing larger-sized particles, which have a smaller optical depth per unit mass, and settle out of the stratosphere faster than smaller particles. Optical depth $(\tau)$ is defined as the negative natural logarithm of the attenuation of incident sunlight, $\tau=-\ln (I / I O)$, where $I o$ and $I$ are the initial and final light intensity, respectively. In the case of volcanic $\mathrm{H}_{2} \mathrm{SO}_{4}$ aerosols, $\tau=6.5 \times 10^{-15} M$, where $M$ is the global aerosol loading in grams (Stothers, 1984a,b). For volcanic aerosols and dust, $\tau$ is largely dependent on the single scattering albedo $(\omega)$ of the cloud, whereas for soot (smoke) clouds, the absorption optical depth $\tau_{a}$ is primar- ily a function of the high absorptivity of the soot particles in the visible (fluffy soot is also highly absorptive in the infrared). For volcanic $\mathrm{H}_{2} \mathrm{SO}_{4}$ aerosols and dust, $\omega$ is about 1 , and therefore, formally, $\tau_{a}$ is $\sim 0$.

In the $10^{14} \mathrm{~g} \mathrm{SO}_{2}$ simulation of Pinto et al. (1989), aerosol optical depth $(\tau)$ reaches a peak of 1.3 within 5 months, with a lifetime of about $2 \mathrm{yr}$, in good agreement with observations for aerosols from the 1815 A.D. Tambora eruption. However, the maximum sulfurvolatile emission that they modeled was $2 \times 10^{14} \mathrm{~g}$ of $\mathrm{SO}_{2}$, so at present there are no data on the behavior of $\mathrm{H}_{2} \mathrm{SO}_{4}$ aerosols in much denser clouds.

The amount of water in the stratosphere is a possible limitation on aerosol loading. Stothers et al. (1986) calculated that, ignoring any water injected into the stratosphere by the eruption itself, about $4 \times 10^{15} \mathrm{~g}$ of water might be available in the form of $\mathrm{H}_{2} \mathrm{O}$ (and $\mathrm{CH}_{4}$ ) to convert $\mathrm{SO}_{2}$ to $\mathrm{H}_{2} \mathrm{SO}_{4}$. From indirect measurements, Hofmann (1987) concluded that the smaller 1982 El Chichón eruption increased stratospheric water, and so a total release of as much as $5.4 \times 10^{17} \mathrm{~g} \mathrm{H}_{2} \mathrm{O}$ from Toba is possible (Rose and Chesner, 1990); in this case, more than enough water may have been present in the stratosphere to convert the estimated $3 \times 10^{15} \mathrm{~g}$ of sulfur gases emitted by Toba into $\sim 1 \times 10^{16} \mathrm{~g}$ of $\mathrm{H}_{2} \mathrm{SO}_{4}$ aerosols. To be conservative, however, and also in agreement with aerosol values extrapolated from historic eruptions, we here infer that only $10 \%$ of the total amount of aerosols possible was actually formed in the Toba cloud, or $\sim 1 \times 10^{15} \mathrm{~g}$ of $\mathrm{H}_{2} \mathrm{SO}_{4}$ aerosols.

The 1815 A.D. Tambora eruption (estimated $\sim 2 \times 10^{14}$ $\mathrm{g}$ of stratospheric aerosols) may be related to an observed Northern Hemisphere surface temperature decrease of $\sim 0.7^{\circ} \mathrm{C}$ in the year following the eruption (Stothers 1984a). If we infer that the relationship between Northern Hemisphere cooling and aerosol loading from large eruptions is approximately linear, a $1 \times 10^{15} \mathrm{~g}$ aerosol loading would lead to a $3.5^{\circ} \mathrm{C}$ hemispheric cooling. However, Devine et al. (1984) developed an empirical formula that relates Northern Hemisphere temperature decreases to estimates of sulfuric acid aerosol yield from historic volcanic eruptions. In their estimate (Devine et al., 1984; Palais and Sigurdsson, 1989), temperature decreases appear to vary approximately in proportion to the $1 / 3$ power of measures of sulfuric acid yield. Extending this empirical relationship to eruptions producing $\sim 1 \times 10^{15} \mathrm{~g}$ of stratospheric aerosols suggests a possible hemispheric surface-temperature decrease resulting from Toba aerosols of about $4 \pm 1^{\circ} \mathrm{C}$.

\section{VOLCANIC WINTER}

A stratospheric aerosol burden estimate for Toba of $1 \times$ $10^{15} \mathrm{~g}$ yields a global aerosol optical depth $(\tau)$ of about 10 (Rampino and Self, 1992). If one considers the injection into the stratosphere of $10 \%$ of the estimated fine dust 
generated, then a short-term (a few months) dust cloud of optical depth $\sim 10$ is also produced. Since Toba is located at low latitudes, dust and volatiles could have been injected efficiently into both Northern and Southern Hemispheres (Rampino et al., 1988). These estimated aerosol optical depths $(\tau=10$ to 20$)$ are roughly equivalent in visible opacity to smoke-cloud absorption optical depths, $\tau_{a}$ of $\sim 2$ (Rampino and Self, 1992). Local and regional optical depth perturbations may have been even greater, especially for the first few months after the eruption, when significant amounts of silicate dust were present in the atmosphere.

Nuclear winter model simulations (Turco et al., 1990) predict average absorption optical depths $\left(\tau_{a}\right)$ of up to 2 to 3 on hemispheric scales, and climate models (General Circulation Models; GCMs) predict that (for a worst-case July smoke injection) land temperatures in the $30^{\circ}$ to $70^{\circ} \mathrm{N}$ zone could drop from $\sim 5^{\circ}$ to $\sim 15^{\circ} \mathrm{C}$, with freezing events in midlatitudes during the first months. During the next 1 to 3 years, global average $\tau_{a}$ of $\sim 0.5$ could persist, with significant cooling in areas covered by the smoke cloud, and ocean-surface cooling of $-2^{\circ}$ to $6^{\circ} \mathrm{C}$ that may extend for several years. Longer term (decadal) climatic cooling might arise primarily through climate feedbacks including increased snow cover and sea ice and perturbed seasurface temperatures.

The injection of $\sim 10^{15} \mathrm{~g}$ of volcanic dust into the stratosphere by an eruption such as Toba, capable of producing aerosol optical depths of $\sim 10$, might be expected to lead to similar immediate surface cooling, creating a so-called "volcanic winter" (Rampino et al., 1988; Rampino and Self, 1992), although volcanic dust probably has a shorter residence time in the atmosphere (3 to 6 months) than possibly self-lofting soot (Turco et al., 1990). The associated stratospheric injection of $\sim 10^{15} \mathrm{~g}$ of sulfur volatiles, and the time required for the formation and spread of volcanic $\mathrm{H}_{2} \mathrm{SO}_{4}$ aerosols in the stratosphere, however, should lead to an extended period of increased atmospheric opacity and surface cooling after the largest eruptions (Rampino and Self, 1992).

\section{CLIMATE CHANGE AT THE TIME OF THE TOBA ERUPTIONS}

The Toba eruption occurred during the oxygen-isotope stage 5a-4 transition recognized in deep-sea cores (Ninkovich et al., 1978; Dehn et al., 1991) (Fig. 3). This transition represents the episode of most rapid ice accumulation, and the main Northern Hemisphere warm-cold climatic transition, during the last glacial cycle (Fig. 3). At the time, sea level is estimated to have dropped by some $40 \mathrm{~m}$ in less than 7000 yr (Ruddiman, 1977a,b). The first significant peak in ice-rafted detritus in the midNorth Atlantic during the last glacial cycle occurred at the same time (Heinrich, 1988), suggesting a rapid expansion of ice sheets. Summer and winter sea-surface temperatures in the North Atlantic (Sancetta et al., 1972) decreased by about $10^{\circ} \mathrm{C}$ in less than $5000 \mathrm{yr}$ (Fig. 3), the
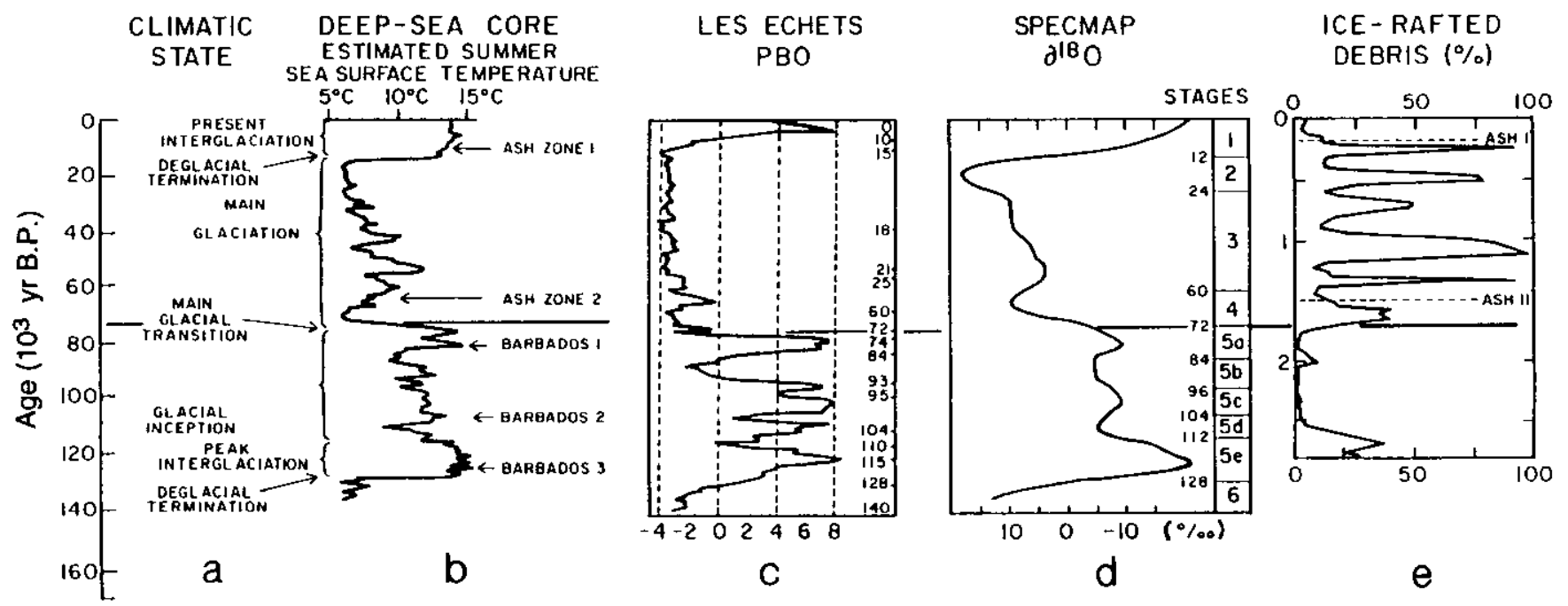

FIG. 3. Climatic indicators for the last $140,000 \mathrm{yr}$, showing climate conditions at the isotope stage 5a-4 boundary (a) Climatic states during the last interglacial-glacial-interglacial cycle (Ruddiman, 1977). (b) Reconstructed summer sea-surface temperatures from planktonic foraminiferal faunal assemblage data, deep-sea core V23-82, North Atlantic (Sancetta et al., 1972). Dated horizons: Ash Zone 1 (9500 yr), Ash Zone 2 (65,000 yr), Barbados 1 Terrace $(\sim 85,000$ yr), Barbados 2 Terrace $(\sim 110,000$ yr), and Barbados 3 Terrace $(\sim 125,000$ yr ago). (c) Palaeobioclimatic Operator $(\mathrm{PBO})$, a measure of the "best possible" climate profile based on multivariate statistical analysis of fossil vegetation changes. Time series reconstructed from Les Echets, France pollen records. Higher PBO values indicate warmer climate. Note that vertical scale (expressed as $10^{3}$ yr B.P.) is nonlinear (Guoit et al., 1989). (d) Stacked, smoothed oxygen-isotope record of deep-sea cores, using the SPECMAP scale. Oxygen-isotope stages and ages of boundaries (10 $0^{3}$ yr B.P.) are shown to the right (Martinson et al., 1987). (e) Percentage of ice-rafted debris, North Atlantic deep-sea core Me69-17. Vertical scale is meters depth in core (Heinrich, 1988). Straight bold line is the best estimated age of the Toba eruption, $74,000 \pm 2000$ уг ago. 
greatest decrease of the last glacial cycle, with salinities showing evidence of a strong polar water advance during isotope stage 4 (Koerner and Fisher, 1985). Ocean cooling lagged behind ice expansion by about 4000 to $5000 \mathrm{yr}$. The subpolar North Atlantic at the midpoint of ice accumulation during the stage $5 \mathrm{a}-4$ transition seems to have been only $1^{\circ}$ to $2^{\circ} \mathrm{C}$ cooler than present (Fig. 3). Much of the large increase in ice volume seems to have occurred adjacent to this warm subpolar ocean, as indicated by the abundance of ice-rafted debris late in the transition. By stage 4 , ice volume reached more than $60 \%$ of the stage 2 full-glacial maximum, implying that snow and ice fields probably spread southward in eastern Canada to about $50^{\circ} \mathrm{N}$ (Ruddiman and McIntyre, 1979).

European pollen records suggest that the cooling began very abruptly (Woillard and Mook, 1982; Guiot, 1990) at $\sim 75,000$ yr B.P. (Fig. 3). Abrupt changes in ocean bottom-water circulation in the Atlantic may account for shifts in benthic fauna at about 115,000 and $75,000 \mathrm{yr}$ B.P. that apparently took place in about $1200 \mathrm{yr}$, close to the mixing time of the oceans (Streeter and Shackleton, 1979). These may have involved a shut-down of North Atlantic Deep-Water formation after a brief episode during isotope substage $5 \mathrm{a}$.

The conditions described above could be interpreted as supporting the concept of rapid "glacierization" developed by Barry et al. (1975). In this view, summer cooling leads to permanent snowfields (Bray, 1977), which would induce snow-albedo feedback. Freshly fallen snow has an albedo $(\alpha)$ of 75 to $95 \%$, and several-day-old snow about 40 to $70 \%$, versus coniferous forest with an $\alpha$ of 5 to $15 \%$, tundra with an $\alpha$ of 15 to $20 \%$, or bare soil with an $\alpha$ of 5 to $35 \%$. The increased snow cover is proposed to lead to a cooler climate, which may lead to further snow and ice accumulation, rapidly leading into a glaciation.

A warm ocean source of moisture might provide increased precipitation. Loewe (1971), for example, suggested that glacierization would occur with a $6^{\circ} \mathrm{C}$ summer cooling plus increased precipitation or with $>6^{\circ} \mathrm{C}$ cooling alone. It has been estimated that glaciation of now-empty cirques on Baffin Island would require either an $80 \%$ increase in snowfall or some combination of increased snowfall, lower summer temperature, and increased cloudiness. Glaciation of eastern Baffin Island is predicted for summer temperatures averaging $4.5^{\circ} \mathrm{C}$ lower than the 1963-1972 average (Ives et al., 1975). Williams (1975), using a GCM, concluded that a cooling of spring and summer temperatures by up to 10 to $12^{\circ} \mathrm{C}$ was required to cause extensive glaciation over Quebec and Labrador under present insolation conditions. These early GCM experiments with specified July snowcover were able to reproduce many of the Northern Hemisphere features of atmospheric circulation thought to be associated with the inception of glaciation during the summer season. However, all of these studies begin with ice-free conditions, whereas the Toba eruption occurred at a time when ice sheets probably already covered $>25 \%$ of the area of the late glacial $(\sim 18,000$ yr B.P.) maximum ice advance.

Summer half-year insolation at $65^{\circ} \mathrm{N}$ was well above modern levels prior to the stage 5a-4 boundary; it had decreased to values lower than those at present by the stage 4 minimum. Within the last interglacial-to-glacial cycle, this drop was exceeded only by the decline during the first phase of glaciation at the substage $5 \mathrm{e}-5 \mathrm{~d}$ boundary $(\sim 115,000$ yr B.P.; Berger, 1978a,b).

Variations in $\mathrm{CO}_{2}$ seem to have lagged climatic change at the 5a-4 stage boundary, and the average atmospheric $p \mathrm{CO}_{2}$ apparently remained relatively constant at around 74,000 yr B.P., even though the Vostok ice core shows cooling. The atmospheric $\mathrm{CO}_{2}$ decrease in isotope stage 4 , from $\sim 245$ to $\sim 195 \mathrm{ppm}$, seems to have occurred only during the final phase of the cooling, dated in the Vostok core from about 71,000 to $62,000 \mathrm{yr}$ B.P. (Jouzel et al., 1987). Atmospheric methane, by contrast, does exhibit a decrease at the $5 \mathrm{a}-4$ boundary from about 600 to $400 \mathrm{ppb}$, but this would produce only a minor climatic effect (Barnola et al., 1978). Increased atmospheric dust content during glacial stages (DeAngelis et al., 1987) has been suggested to cause global cooling of up to $2^{\circ}$ to $3^{\circ} \mathrm{C}$, and we note that the Vostok ice core shows a significant dust peak at $\sim 71,000 \mathrm{yr}$ B.P. An increase in non-sea-salt sulfur in the Vostok core at the isotope stage $5 \mathrm{a}-4$ boundary suggests possible additional cooling from increased cloud cover, estimated at $\sim 0.6^{\circ} \mathrm{C}$ (Legrand et al., 1988).

\section{VOLCANIC AEROSOLS AND GROWTH OF GLACIERS}

It has been suggested that a period of lower than present mean daily summer temperatures over the central plateau of Quebec and Labrador, perhaps accompanied by increased snowfall, would favor the formation of perennial snow cover (Williams, 1979). Some have proposed that these conditions could lead to "instantaneous glacierization" of the high plateaus of the Canadian Arctic within a few hundred years, starting from ice-free conditions (e.g., Loewe, 1971). Several lines of evidence suggest that the atmospheric effects of large volcanic eruptions can cause significant reductions in summer temperatures at the sensitive latitudes for a few years, and that the reduced temperatures might lead to significant short-term changes in ice ablation/accumulation rates. For example, analyses of tree-ring data from northern Quebec show mean summer temperatures for the last 250 years of $9.5^{\circ} \mathrm{C}$, with a lowering of $3.5^{\circ} \mathrm{C}$ (to $\sim 6^{\circ} \mathrm{C}$ ) in 1816 A.D. after the Tambora eruption (Jacoby et al., 1988). From sparse instrumental records, Stothers (1984a) calculated a Northern Hemisphere temperature decrease of about $0.7^{\circ} \mathrm{C}$ in the year after Tambora, so that summer temperature decline in Quebec in 1816 showed 
an $\sim 5$ times amplification of the estimated Northern Hemisphere cooling (although this may have been partly a dynamic effect). Based on these studies, if Toba caused a minimum $3^{\circ} \mathrm{C}$ Northern Hemisphere cooling, then Quebec summer temperatures following the Toba eruption could have been as much as $15^{\circ} \mathrm{C}$ colder than those at present for 2 or 3 years.

Studies utilizing GCMs also suggest that a hemispheric cooling would have been amplified at high latitudes. In coupled atmosphere/ocean GCM experiments, Manabe and Bryan (1985) showed that, in going from $1 / 2 \times \mathrm{CO}_{2}$ to $1 \times \mathrm{CO}_{2}$ atmospheres, zonal mean temperatures at $55^{\circ} \mathrm{N}$ in North America increased by about $20^{\circ} \mathrm{C}$, while the average global climate warmed by about $3^{\circ} \mathrm{C}$. In the $1 / 2 \times$ $\mathrm{CO}_{2}$ model, sea ice extended to middle latitudes, increasing global albedo, and the weakened ocean-thermohaline circulation in the model was largely confined to an area between the sea-ice margin and the equator. If a similar high-latitude amplification for cooling largely through sea-ice albedo also operated at 74,000 B.P., then these GCM results suggest that an $\sim 3^{\circ} \mathrm{C}$ global cooling after the Toba eruption could have led to a significantly amplified mean annual cooling in the region of expected Northern Hemisphere ice growth.

Lowering of the freezing line should have a direct effect on annual snow accumulation. July temperatures on the east shore of Hudson Bay now average $10.6^{\circ} \mathrm{C}(\mathrm{C}$. Wilson, personal communication), and the freezing altitude $\left(0^{\circ}\right.$ isotherm) averages about $2500 \mathrm{~m}$. Therefore, a summertime cooling of only about $10^{\circ} \mathrm{C}$ would be required to bring the $0^{\circ} \mathrm{C}$ isotherm to the ground. In July 1965 , a lowering of $\sim 500$ to $600 \mathrm{~m}$ occurred relative to the average freezing altitude for the decade (Bradley and England, 1978a), and this may have been related to the 1963 eruption of the Agung volcano in Indonesia (or other eruptions). In July 1816 , the $-6^{\circ} \mathrm{C}$ summer anomaly seems to have produced a $1000-\mathrm{m}$ drop in the freezing altitude (Wilson, 1985). We note that there were only 5 weeks without measurable snowfall at sites along eastern Hudson Bay in 1816.

The Toba aerosol cloud, predicted to cause a summer temperature anomaly of the order of $-12^{\circ}$ to $15^{\circ} \mathrm{C}$, would bring the atmospheric freezing altitude in July down to ground level under present climate conditions. Under conditions in which snow and ice already cover a significant area in North America, and with greater extent of sea ice, as seems to have been the case when Toba erupted, we infer that a smaller reduction in summer temperatures would have been sufficient to tip the balance toward annual snow accumulation in areas adjacent to those of established ice cover.

In a recent simulation using the Goddard Institute for Space Studies (GISS) GCM, volcanic aerosols causing an optical-depth perturbation of 0.1 for $5 \mathrm{yr}$ led to a global surface cooling of about $0.5^{\circ} \mathrm{C}$, with a reduction in sum- mer temperatures in Canada at $\sim 55^{\circ} \mathrm{N}$ of about $2^{\circ} \mathrm{C}$, or 4 times the global average (Rampino and Self, 1992). If high-latitude seasonal amplification is roughly linear with the magnitude of the temperature decrease, then these results predict that a possible $3^{\circ} \mathrm{C}$ global cooling after the Toba eruption could have led to an $\sim 12^{\circ} \mathrm{C}$ reduction in summer temperatures for $\sim 2$ to 3 years in the areas of growth of the Laurentide ice sheet, in good agreement with the empirical estimates discussed above.

Evidence exists that volcanic aerosol perturbations can lead to reductions in ice-ablation rates and may be an important forcing mechanism for glacial variations on decadal time scales. Bradley and England (1978a) have shown that periods with reduced summer temperatures, such as that which followed the Agung eruption in 1963, are also periods of significantly reduced ice ablation. For the Devon Island ice cap, ablation losses during an interval free of volcanic aerosols were a factor of 10 greater than losses during the period affected by the 1963 aerosol event (Bradley and England, 1978b).

Porter (1986) has suggested that mean annual temperature reductions related to historic volcanic eruptions $\left(\sim 0.2^{\circ}\right.$ to $0.7^{\circ} \mathrm{C}$ for the Northern Hemisphere, but amplified by about a factor of $\sim 4$ to 5 at high northern latitudes) may be sufficient to significantly depress the equilibrium-line altitudes of alpine glaciers and to cause glacier advances. A consistent correlation between periods of mountain glacier advance and intervals of increased volcanic aerosols (as evidenced by higher acidity levels in ice cores) suggests that volcanism may have been an important control on glacier movements during the last 1500 yr (Porter, 1986). In a quantitative test of Porter's proposed relationship, using a simple climate-glacier model, volcanic forcing (the Greenland ice-acidity record and Dust Veil Index values) and recent $\mathrm{CO}_{2}$-induced warming produced glacier variations in good agreement with historical observations (Oerlemans, 1988). In contrast, however, both Wigley (1991) and Rind (1991) suggest that ice-core acidity data preclude volcanic aerosol optical depths capable of forcing known Holocene glacier advances.

\section{MODELS OF ICE-SHEET GROWTH AND THE STAGE 5a-4 BOUNDARY}

Recent model simulations of ice-sheet evolution suggest that the rapid growth of ice sheets at the 5a-4 boundary could have been accomplished without any additional forcing from volcanic aerosols. For example, Fichefet $e t$ al. (1989) used a two-dimensional zonally averaged climate model coupled with an ice-sheet model to investigate the evolution of Northern Hemisphere ice sheets over the last glacial/interglacial cycle. Using the seasonal insolation cycle (with no trace-gas forcing), new ice sheet growth was initiated in a latitudinal belt whenever the 
annual snow-mass balance was positive in the seasonal climate model. The coupled model gives $\sim 8 \times 10^{6} \mathrm{~km}^{3}$ of ice at the isotope substage 5a peak and rapidly produces an additional $15 \times 10^{6} \mathrm{~km}^{3}$ of ice (mostly in North America) in isotope stage 4 , in excellent agreement with the inferred isotope and sea-level changes at the time (Chappell and Shackleton, 1986). A two-dimensional, one-level seasonal climate model coupled to ice-flow models gave similar results (Deblonde and Peltier, 1990).

These models take about 15,000 yr $(\sim 80,000$ to $\sim 65,000$ yr B.P.) to simulate the entire $5 \mathrm{a}-4$ interglacialglacial transition, in general agreement with the observations, although the most rapid part of the actual icegrowth transition may have taken place in much less time. The results of the models are quite good, although it should be remembered that they are simplified and contain many parameterizations of physical processes. The results suggest that additional climate forcings from increased stratospheric aerosols may not be required to produce the growth of ice sheets at the stage 5a-4 boundary, but they do not rule out a contribution from volcanic cooling.

Recent studies of ice-sheet growth using more sophisticated GCMs, however, give conflicting results. These experiments, in general, have attempted to grow ice sheets starting from ice-free or almost ice-free conditions. For example, using one version of the NCAR Community Climate Model, Oglesby (1990) has found that an initial imposition of $1 \mathrm{~m}$ of snow over the Northern Hemisphere under present conditions results in retention and increase in snow depth, in some glaciation-sensitive areas such as Alaska, western Canada, Siberia, and the Tibetan Plateau. When atmospheric $\mathrm{CO}_{2}$ was reduced to $200 \mathrm{ppm}$ in the model, glaciation-sensitive areas appeared in all regions in which late Pleistocene ice sheets actually grew (the Vostok Ice Core suggests atmospheric $p \mathrm{CO}_{2}$ of 240 ppm at $\sim 74,000$ yr B.P.). These results suggest that an initial increase in snow cover under today's climate could lead to glaciation in some "sensitive" areas. The results also argue that model runs using the cooler initial climate and favorable orbital forcing of $\sim 74,000 \mathrm{yr}$ B.P. would result in improved retention and increase in ice cover for these and other critical regions.

By contrast, experiments using the GISS GCM were unable to initiate the growth of Northern Hemisphere ice sheets even with the low-summer insolation fields of 116,000 and $106,000 \mathrm{yr}$ B.P. and also times of rapid growth of ice sheets (Rind et al., 1989). The model could not maintain snow cover through the summer. The GISS model experiments also failed to maintain a 10 -m-thick ice cover that was inserted in areas in which continental ice existed during the last glaciation, even with an additional forcing from reduced atmospheric $\mathrm{CO}_{2}$.

Taken at face value, these results suggest that, starting from ice-free or near ice-free conditions, snow and ice accumulated during a few years of decreased summer temperatures, as in a volcanic winter, would be lost to ablation in the normal summers that followed. However, experiments with realistic ice-cover conditions at $\sim 74,000$ yr B.P. have not been run, so we cannot directly determine the effects of considerable preexisting landand sea-ice on further ice accumulation. Furthermore, the mixed GCM results suggest important differences in individual model sensitivity to factors involved in ice accumulation, and until these factors are better understood, no firm conclusions should be drawn regarding the conditions under which ice sheets will begin to grow.

\section{EXPLOSIVE VOLCANISM AND GLACIATION: PROPOSED FEEDBACK MECHANISMS}

The relationship between historical volcanic aerosol perturbations and short-term climate changes is wellsupported by empirical studies and theoretical models (Rampino et al., 1988), Moreover, many studies over the years have argued for a possible relationship between volcanic eruptions and glaciations (e.g., Kennett and Thunell, 1975). In recent years, the success of Milankovitch orbital parameters and related changes in atmospheric chemistry in explaining the timing of Quaternary climate variations have largely superseded any general volcanic explanation (Berger, 1984). The question remains, however, as to the effects of the largest eruptions on long-term global climate.

The empirical analyses and model experiments summarized here provide some support for the idea that several years of cool summers at high northern latitudes predicted in the aftermath of Toba might have contributed to the acceleration of ice-sheet growth and global cooling at $\sim 74,000$ yr B.P. Empirical results suggest that the Toba aerosol perturbation could have produced climatic conditions conducive to snow and ice accumulation in glaciation-sensitive regions. Simplified coupled models of climate and ice-sheet growth at least do not rule out a contribution from volcanic aerosol cooling, and the success of GCMs in growing ice sheets using insolation and $\mathrm{CO}_{2}$ forcings has thus far been mixed. Of critical importance is the fact that Toba erupted at a sensitive time in the Milankovitch insolation cycle, and at a time when significant ice cover already existed, during the isotope stage $5 \mathrm{a}-4$ transition. This timing might be crucial to the effectiveness of a brief volcanic winter in affecting long-term climate.

Although the very short-term climatic effects of Toba cannot be seen at the present resolution of available proxy climate data, the eruption may have left a signature on global climate through possible feedback effect. The detailed climate record of the stage 5a-4 transition (Ruddiman et al., 1980) reveals that sea-level lowering was underway at the time of the Toba eruption, but that North Atlantic surface-ocean temperatures remained warm 
(Fig. 4). Coincident with the Toba eruption, North Atlantic surface temperatures and global sea level dropped precipitously. Smit et al. (1991) found evidence that the lysocline in the eastern Indian Ocean became shallower rather suddenly at the time of the Toba ash deposition, and they attributed this to the effects of the eruption. Regionally, the effect on ocean biota of the fallout of $\sim 4$ $\mathrm{g} / \mathrm{cm}^{2}$ of Toba ash over an area of $5 \times 10^{6} \mathrm{~km}^{2}$ of the Indian Ocean must have been considerable. Deposition rates of nitrogen, organic carbon, and $\mathrm{CaCO}_{3}$ all rise sharply in the first few centimeters of the Toba ash layer, indicating that the ash fallout swept the water column of most of its particulate organic carbon and calcium carbonate (Gilmour et al., 1990).

Other large eruptions during abrupt coolings show a similar timing. For example, the isotope substage $7 \mathrm{c}-7 \mathrm{~b}$ boundary $(\sim 230,000$ yr B.P.), a time of reduced highlatitude summer insolation and possibly the most rapid accumulation of ice in the late Pleistocene (Ruddiman and McIntyre, 1979), is marked by a widespread ash layer (Layer " $L$ ") in eastern equatorial Pacific sediment cores (Ninkovich and Shackleton, 1975). However, the ash layer occurs more than half-way through the isotopic transition, so that although the eruption was apparently not a factor in the initial build-up of glacier ice, it could have contributed to the rapid growth of ice sheets.

\section{Volcanism and Milankovitch Parameters}

Dated eruptions of Toba have occurred at $\sim 74,000$, $450,000,840,000$, and 1.2 million yr B.P. (Chesner et al.,
1991), giving a mean interval of $375,000 \mathrm{yr}$ with a standard deviation of only 15,000 yr (Dehn et al., 1991). These authors also recently found that major $(>1 \mathrm{~cm}$ thick) volcanic ash layers from Indonesian eruptions (including Toba) recorded in Indian Ocean cores occur approximately every $414,000 \mathrm{yr}$ with the most recent grouping of ashes beginning about 2.4 myr. The $\sim 400,000-y r$ mean interval in Indonesian volcanism is close to the 413,000 -yr cycle of the earth's eccentricity, and the initiation of the last grouping at $\sim 2.4$ myr B.P. correlates with the beginning of severe Northern Hemisphere glaciation. The Toba eruption at $840,000 \mathrm{yr}$ B.P. also correlates with the mid-Pleistocene shift in dominance from a $40,000-\mathrm{yr}$ early Pleistocene rhythm to the 100,000-yr late Pleistocene rhythm (Ruddiman et al., 1980).

Are these correlations merely coincidences? Milankovitch band cycles have been detected in records of volcanism from other areas. Late Quaternary ash layers in deep-sea cores from the Mediterranean (Paterne et al., 1990), and from Crozet Island (Paterne et al., 1991) in the Indian Ocean, have been found to show a $\sim 23,000-y r$ periodicity, similar to the earth's precessional period. Icelandic (Sioholm et al., 1991) and Japanese eruptions (Caldeira and Rampino, 1992) during the Quaternary show an apparent $\sim 100,000-y r$ cycle. These findings suggest that volcanic activity itself might be related to Milankovitch parameters, perhaps through stress changes by water loading and unloading on magma chambers during sea-level fluctuations (see Matthews, 1969; Rampino et al., 1979) or, in the case of Iceland, direct isostatic effects of fluctuating ice sheets (Sigvaldason et al., 1992).
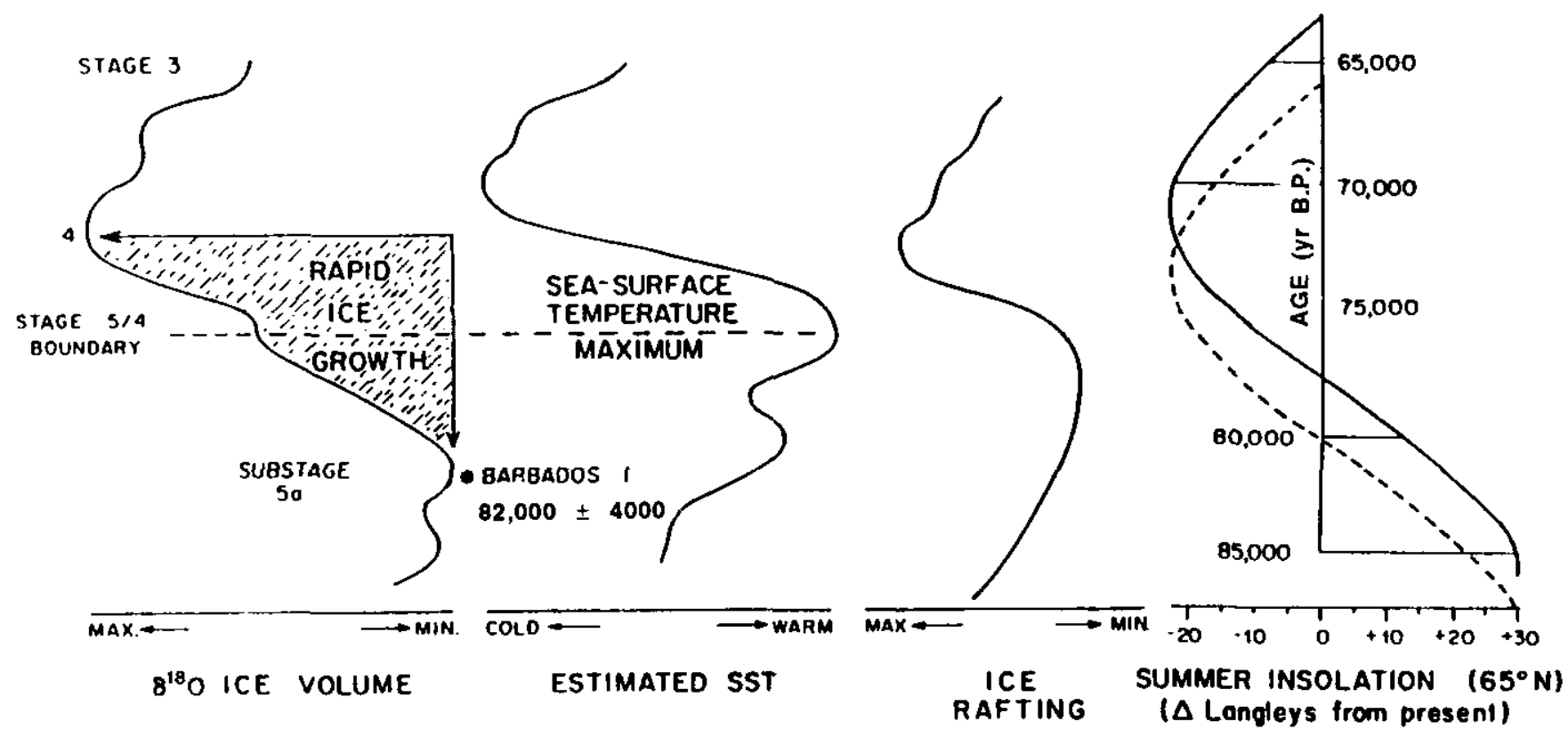

FIG. 4. Schematic representation of the changes in parameters critical to Northern Hemisphere glaciation at the stage 5a-4 boundary (Ruddiman et al., 1980). Ocean-core data are precisely intercorrelated, but have a dating uncertainty of about 2500 to $3000 \mathrm{yr}$. Dotted line indicates different correlation of radiation curve (Berger, 1978) with ocean-core data if the stage 5a-4 boundary is 2500 yr younger than the commonly assumed value of $75,000 \mathrm{yr}$ B.P. The timing of the Toba eruption is formally $74,000 \pm 2000 \mathrm{yr}$ ago, and it may match the timing of rapid sea-surface temperature decline, increase in ice rafting, and steepening of the sea-level fall curve. 
Recently, Nakada and Yokose (1992) have shown that the vertical gradient of horizontal stress difference in the lithosphere for loadings of $+130 \mathrm{~m}$ of sea level reaches $\sim 8$ $\mathrm{bar} / \mathrm{km}$, enough to cause propagation of magma-filled cracks. The total change in stress difference during an $\sim 10,000$-yr glacial/interglacial transition is $\sim 130$ bars, which is $\sim 50 \%$ of the tectonic stresses in Japan.

A possible volcanic triggering mechanism in which a $24,000 \mathrm{yr}$ periodicity was detected in geochemical variations in Mediterranean eruptions, possibly caused by injection of deeper-derived magma into shallow magma chambers, is suggested by the study of Paterne and Guichard (1993). This magma-mixing trigger mechanism is commonly recognized to operate (the $1991 \mathrm{Mt}$. Pinatubo eruption is a recent example; Pallister et al., 1992), and was earlier suggested by us as a potential trigger in climate-modulated volcanism (Rampino et al., 1979). It has been noted elsewhere that very small pressure variations $(\sim 1$ bar) in magma chambers can lead to transitions in eruption regime (e.g., Jaupart and Allégre, 1991).

Clusters of eruptions seem to take place during some rapid climatic transitions. For example, North Atlantic ash zone I contains at least four Icelandic tephra horizons dated at $\sim 10,800,10,600$ (Skogar Tephra), 9300 and 8900 yr B.P., spanning the glacial-interglacial transition and the Younger Dryas cool interval (Sejrup et al., 1989; Bjork et al., 1972). Increased volcanism during the Younger Dryas, in general, is summarized by Dawson (1991). The Skogar Tephra is correlated with the widespread Vedde Ash in western Norway and the North Sea (Mangerud et al., 1984; Norddahl and Haflidason, 1992) and marks the Younger Dryas interval of very rapid climatic change. In southern Alaska, the Mount Edgecumbe Tephra deposits were erupted within less than 1000 yr at $11,000-10,600$ yr B.P. (Riehle et al., 1992), and in the Cascades, Glacier Park eruptions dated at 11,200 yr (Busacca et al., 1992) occurred at about the same time.

It has been proposed that abrupt jumps from one stable climate mode to another characterize glacial-tointerglacial transitions (e.g., at $\sim 115,000$ and $\sim 74,000 \mathrm{yr}$ B.P.), and these abrupt changes could involve major reorganizations of the ocean-atmosphere system (Broecker and Denton, 1990). The climate of the late Pleistocene, and especially the dominant 100,000 -yr periodicity, has been modeled as a bistable system, where the response to external orbital forcing is amplified by normal "weather" fluctuations, internal to the climate system, through the mechanism of stochastic resonance. Thus, glacial and interglacial climates might represent two stable end states, with stochastic noise driving the climate system from one end to another, and with abrupt transitions between them (Saltzman, 1982). Stochastic noise usually reflects the natural variability of the climate system (Matteucci, 1989), but the climatic conditions of a volcanic winter, especially if it occurred at a critical time in the orbitally paced insolation/greenhouse-gas cycle, could provide the kind of random forcing event needed to flip the system from an interglacial to a glacial mode.

\section{CONCLUSIONS}

The great Toba ignimbrite eruption of $\sim 74,000$ yr B.P. has provided evidence for possible general connections between volcanic eruptions and climate change. The "volcanic winter" predicted in the aftermath of Toba may have accelerated an interval of global cooling. Toba occurred during a major climatic transition and might have been triggered by stresses caused by changes in sea level. There may be a general correlation of large eruptions or clusters of eruptions at climate transitions, and these could provide important feedbacks to the climatic change: positive feedback during warm-cold transitions and negative feedback during cold-warm transitions. The detection of Milankovitch band periodicities in the frequency, and possibly in the composition, of volcanic eruptions suggests that the climate and volcanic systems may be coupled in a way that might explain the correlation between eruptions and periods of climate change so often noted in the literature.

\section{ACKNOWLEDGMENTS}

We thank J. T. Andrews, C. Fletcher, D. Peteet, W. F. Ruddiman, S. H. Schneider, H. Sigurdsson, R. B. Stothers, and G. P. L. Walker for critical reviews of earlier versions of this paper and T. Gerlach, G. Matteucci, D. Rind, W. I. Rose, C. Sagan, H. Sigurdsson, R. Turco, K. Caldeira, and A. W. Woods for helpful comments, discussions, and/or unpublished information. Supported by grants from NASA (NAG 5-1839 to S.S.), DOE-NIGEC, NATO, and the Center for Global Habitability at Columbia University.

\section{REFERENCES}

Acharyya, S. K. (1993). The Toba ash-bed marker from the Indian subcontinent: Its implications on correlation of Late Pleistocene alluvial conditions and assessment of paleoclimatic conditions. Quaternary Research 40, 10-19.

Barnola, J. M., Raynaud, D., Korotkevich, Y. S., and Lorius, C. (1987). Vostok ice core provides 160,000 year record of atmospheric $\mathrm{CO}_{2}$. Nature 329, 408-414.

Barry, R. C. Andrews, J. T., and Mahaffy, M. A. (1975). Continental ice sheets: Conditions for growth. Science 190, 979-981.

Berger, A. L. (1978a). Long-term variations of daily insolation and Quaternary climatic changes. Journal of the Atmospheric Sciences $35,2362-2367$.

Berger, A. L. (1978b). Long-term variations of caloric insolation resulting from the Earth's orbital elements. Quaternary Research 9, 139167.

Berger, A. L. (1984). Accuracy and frequencies stability of the Earth's orbital elements during the Quaternary. In "Milankovitch and Climate, Parts 1 and 2" (A. L. Berger et al., Eds.), pp. 3-40. Reidel, Dordrecht.

Bjork, S., Ingolfsson, O., Haflidason, H., Hallsdottir, M., and Anderson, N. J. (1992). Lake Torfadalsvatn: A high resolution record of the 
North Atlantic ash zone I and the last glacial-interglacial environmental changes in Iceland. Boreas 21, 15-22.

Bradley, R. S., and England, J. (1978a). Recent climatic fluctuations of the Canadian high Arctic and their significance for glaciology. Arctic and Alpine Research 10, 715-731.

Bradley, R. S., and England, J. (1978b). Volcanic dust in influence on glacier mass balances at high latitudes. Nature 271, 736-738.

Bray, J. R. (1977). Pleistocene volcanism and glacial initiation. Science 197, 251-254.

Broecker, W. S., and Denton, G. H. (1990). The role of oceanatmosphere reorganizations in glacial cycles. Quaternary Science Reviews 9, 305-341.

Busacca, A. J., Nelstead, K. T., McDonald, E. V., and Purser, M. D. (1992). Correlation of distal tephra layers in loess in the channeled scabland and palouse of Washington state. Quaternary Research 37, 281-303.

Caldeira, K., and Rampino, M. R. (1992). Mount Etna $\mathrm{CO}_{2}$ may affect climate. Nature 355, 401-402.

Caress, M. (1985). "Volcanology of the Younger Toba Tuff, Sumatra." Unpublished Masters dissertation, University of Hawaii at Manoa.

Carey, S. N., Sigurdsson, H., and Sparks, R. S. J. (1989). Experimental studies of particle-laden plumes. Journal of Geophysical Research 93, 15314-15328.

Chappell, J., and Shackleton, N. J. (1986). Oxygen isotopes and sea level. Nature 324, 137-140.

Chesner, C. A., Rose, W. I., Deino, A., Drake, R., and Westgate, J. A. (1991). Eruptive history of Earth's largest Quaternary caldera (Toba, Indonesia) clarified. Geology 19, 200-203.

Dawson, A. (1991). "Ice Age Earth: Late Quaternary Geology and Climate," pp. 180-198. Rutledge, London.

DeAngelis, M., Barkov, N. I., and Petrov, V. N. (1987). Aerosol concentrations over the last climatic cycle (160 ka) from an Antarctic core. Nature 325, 318-321.

Deblonde G., and Peltier, W. R. (1990). A model of late Pleistocene ice sheet growth with realistic geography and simplified cryodynamics and geodynamics. Climate Dynamics 5, 103-110.

Dehn, J., Farell, J. W., and Schmincke, H.-U. (1991). Neogene tephrochronology from Site 758 on Northern Ninetyeast Ridge: Indonesian arc volcanism of the past 5 Ma. Proceedings of the Ocean Drilling Program, Scientific Results 121, 273-295.

Devine, J. D., Sigurdsson, H., Davis, A. N., and Self, S. (1984). Estimates of sulfur and chlorine yield to the atmosphere from volcanic eruptions and potential climatic effects. Journal of Geophysical Research 89, 6309-6325.

Dobran, F., Neri, A., and Macedonio, G. (1992). "Numerical Simulation of Collapsing Volcanic Columns." Volcanic Simulation Group Report No. 92-2. Gruppo Nazionale per la Volcanologia, Pisa.

Fichefet, T., Tricot, C., Berger, A., Gallee, H., and Marsiat, I. (1989). Climatic studies with a coupled atmosphere-upper-ocean-ice-sheet model. Philosophical Transactions of the Royal Society of London, Series A329, 249-261.

Fierstein, J., and Nathanson, M. (1992). Another look at the calculation of fallout tephra volumes. Bulletin of Volcanology 54, 233-254.

Gilmour, I. Wolbach, W. S., and Anders, E. (1990). Early environmental effects of the terminal Cretaceous impact. Geological Society of America Special Paper 247, 383-390.

Guiot, J. (1990). Methodology of the last climatic cycle reconstruction in France from pollen data. Palaeogeography, Palaeoclimateology, Palaeoecology 80, 49-69.

Guiot, J., Pons, A., de Beaulieu, J. L., and Reille, M. (1989). A 140,000year continental climate reconstruction from two European pollen records. Nature 338, 309-313.

Heinrich, H. (1988). Origin and consequences of cyclic ice rafting in the Northeast Atlantic Ocean during the past 130,000 years. Quaternary Research 29, 142-152.

Hofmann, D. J. (1987). Perturbations of the global atmosphere associated with El Chichón volcanic eruption of 1982 . Reviews of Geophysics 25, 743-759.

Ives, J. D., Andrews, J. T., and Barry, R. G. (1975). Growth and decay of the Laurentide Ice Sheet and comparisons with FennoScandinavia. Naturwissenschaften 62, 118-125.

Jacoby, G. C., Ivanciu, I. S., and Ulan, L. D. (1988). A 263-year record of summer temperature for northern Quebec reconstructed from treering data and evidence of a major climatic shift in the early 1800 's. Palaeogeography, Palaeoclimatology, Palaeoecolology 64, 69-78.

Jaupart, C., and Allegre, C. J. (1991). Gas content, eruption rate and instabilities of eruption regime in silicic volcanoes. Earth and Planetary Science Letters 102, 413-429.

Jouzel, J., et al. (1987). Vostok ice core: A continuous isotope temperature record over the last climatic cycle $(160,000$ years). Nature 329 , 403-418.

Kennett, J. P., and Thunell, R. C. (1975). Global increase in Quaternary explosive volcanism. Science 187, 497-503.

Koerner, R. M., and Fisher, D. A. (1985). In "Late Quaternary Environments: Eastern Canadian Arctic, Baffin Bay and West Greenland" (J. T. Andrews, Ed.), pp. 309-327. Allen and Unwin, London.

Koyaguchi, T., and Tokuno, M. (in press). Origin of the giant eruption cloud of Pinatubo, June 15, 1991. Journal of Volcanology and Geothermal Research.

Ledbetter, M. T., and Sparks, R. S. J. (1979). Duration of largemagnitude explosive eruptions deduced from graded bedding in deepsea ash layers. Geology 7, 240-244.

Legrand, M. R., Delmas, R. J., and Charlson, R. J. (1988). Climate forcing implications from Vostok ice-core sulphate data. Nature 334, 418-420.

Loewe, F. (1971). Considerations of the origin of the Quaternary Ice Sheet of North America. Arctic and Alpine Research 3, 331-334.

Manabe, S., and Bryan, K., Jr. (1985). $\mathrm{CO}_{2}$-induced change in a coupled ocean atmosphere model and its paleoclimatic implications. Journal of Geophysical Research 90, 11689-11707.

Mangerud, J., et al. (1984). A younger Dryas ash bed in western Norway, and its possible correlations with tephra in cores from the Norwegian Sea and the North Atlantic. Quaternary Research 21, 85-104.

Martinson, D. G., et al. (1987). Age dating and the orbital theory of the Ice Ages: Development of a high-resolution 0 to 300,000 -year chronostratigraphy. Quaternary Research 7, 1-29.

Matteucci, G. (1989). Orbital forcing in a stochastic resonance model of the Late-Pleistocene climatic variations. Climate Dynamics 3, 179190.

Matthews, R. K. (1969). Tectonic implication of glacio-eustatic sea level fluctuations. Earth and Planetary Science Letters 5, 459-462.

Nakada, M., and Yokose, H. (1992). Ice age as a trigger of active Quaternary volcanism and tectonism. Tectonophysics 212, 321-329.

Ninkovich, D., and Shackleton, N. J. (1975). Distribution, stratigraphic position, and age of ash layer " $L$ ", in the Panama Basin. Earth and Planetary Science Letters 27, 20-34. 
Ninkovich, D., Shackleton, N. J., Abdel-Monem, A. A., Obradovich, J. A., and Izett, G. (1978). K-Ar age of the late Pleistocene eruption of Toba, north Sumatra. Nature 276, 574-577.

Norddahl, H., and Haflidason, H. (1992). The Skogar Tephra, a Younger Dryas marker in North Iceland. Boreas 21, 23-41.

Oerlemans, J. (1988). Simulation of historic glacier variations with a simple climate-glacier model. Journal of Glaciology 34, 333.

Oglesby, R. J. (1990). Sensitivity of glaciation to initial snow cover, $\mathrm{CO}_{2}$, snow albedo, and oceanic roughness in the NCAR CCM. Climate Dynamics 4, 219-235.

Palais, J. M., and Sígurdsson, H. (1989). Petrologic evidence of volatile emissions from major historic and pre-historic volcanic eruptions. American Geophysical Union, Geophysical Monograph 52, 32-53.

Pallister, J. S., Hoblitt, R. P., and Reyes, A. G. (1992). A basalt trigger for the 1991 eruptions of Pinatubo volcano? Nature 356, 426-428.

Paterne, M., and Guichard, F. (1993). Triggering of volcanic pulses in the Campanian area, South Italy, by periodic deep magma influx. Journal of Geophysical Research 98, 1861-1873.

Paterne, M., Labeyrie, J., Guichard, F., Mazaud, A., and Maitre, F. (1990). Fluctuations of the Campanian explosive volcanic activity (South Italy) during the past 190,000 years as determined by marine tephrochronology. Earth and Planetary Science Letters, 98, 166-174.

Paterne, M., Labeyrie, J., Guichard, F., Mazaud, A., and Maitre, F. (1991). "Fluctuations of the Campanian Explosive Volcanic Activity (South Italy) during the Past 190,000 Years as Determined by Marine Tephrochronology," p. 6. IAVCEI, Programs and Abstracts, XX General Assembly, Vienna, IUGG.

Pinto, J. P., Turco, R. P., and Toon, O. B. (1989). Self-limiting physical and chemical effects in volcanic eruption clouds. Journal of Geophysical Research 94, 11165-11174.

Porter, S. C. (1986). Pattern and forcing of Northern Hemisphere glacier variations during the last millennium. Quaternary Research 26 , 27-48.

Rampino, M. R., and Self, S. (1982). Historic eruptions of Tambora (1815), Krakatau (1883), and Agung (1963), their stratospheric aerosols, and climatic impact. Quaternary Research 18, 127-143.

Rampino, M. R., and Self, S. (1992). Volcanic winter and accelerated glaciation following the Toba super-eruption. Nature 359, 50-52.

Rampino, M. R., Self, S., and Fairbridge, R. W. (1979). Can rapid climatic change cause volcanic eruptions? Science 206, 826-829.

Rampino, M. R., Self, S., and Stothers, R. B. (1988). Volcanic winters. Annual Reviews of Earth and Planetary Science 16, 73-99.

Riehle, J. R., Mann, D. H., Peteet, D. M., Engstrom, D. R., Brew, D. A., and Meyer, C. E. (1992). The Mount Edgecumbe tephra deposits, a marker horizon in southeastern Alaska near the PleistoceneHolocene boundary. Quaternary Research 37, 183-202.

Rind, D., Peteet, D., and Kukla, G. (1989). Can Milankovitch orbital variations initiate the growth of ice sheets in a general circulation model? Journal of Geophysical Research 94, 12851-12871.

Rind, D. (1991). The paleorecord: How useful is it in testing models for future climatic prediction? In "Global Changes of the Past" (R. S. Bradley, Ed.), pp. 397-420. UCAR/Office for Interdisciplinary Earth Studies, Boulder.

Rose, W. 1., and Chesner, C. A. (1987). Dispersal of ash in the great Toba eruption, $75 \mathrm{Ka}$. Geology 15, 913-917.

Rose, W. I., and Chesner, C. A. (1990). Worldwide dispersal of ash and gases from earth's largest known eruption: Toba, Sumatra, $75 \mathrm{Ka}$. Global and Planetary Change 89, 269-275.

Ruddiman, W. F. (1977a). North Atlantic ice-rafting: A major change at 75,000 years before the present. Science $196,1208-1211$.
Ruddiman, W. F. (1977). Late Quaternary deposition of ice-rafted sand in the subpolar North Atlantic (lat. $40^{\circ}$ to $65^{\circ} \mathrm{N}$ ). Geological Society of America Bulletin 88, 1813-1827.

Ruddiman, W. F., and McIntyre, A. (1979). Warmth of the subpolar North Atlantic Ocean during northern hemisphere ice-sheet growth. Science 204, 173-175.

Ruddiman, W. F., Mclntyre, A., Niebler-Hunt, V., and Durazzi, J. T. (1980). Oceanic evidence for the mechanism of rapid northern hemisphere glaciation. Quaternary Research 13, 33-64.

Saltzman, B. (1982). Stochastically-driven climatic fluctuations in the sea-ice, ocean temperature, $\mathrm{CO}_{2}$ feedback system. Tellus 34, 97-112.

Sancetta, C., Imbrie, J., Kipp, N. G., McIntyre, A., and Ruddiman, W. F. (1972). Climatic record in North Atlantic deep-sea core V23-82: Comparison of the last and present interglacials based on quantitative time series. Quaternary Research 2, 363-367.

Sejrup, H. P. (1989). Quaternary tephrachronology on the Iceland Plateau, north of Iceland. Journal of Quaternary Science 4, 109-114.

Sigvaldason, G., Annerts, K., and Nilsson, M. (1992). Effect of glacier loading/deloading on volcanism: Postglacial volcanic production rate of the Dyngjufjöll area, central Iceland. Bulletin Volcanologique 54, 385-392.

Sioholm, J., Sejrup, H. P., and Furnes, H. (1991). Quaternary volcanic ash zones on the Iceland Plateau, southern Norwegian Sea. Journal of Quaternary Science 6, 159-173.

Smit, J., van Eijden, and Troelstra, S. R. (1991). Analysis of the Australasian microtektite event, the Toba Lake event, and the Cretaceous/Paleogene boundary, Eastern Indian Ocean. Proceedings of the Ocean Drilling Program, Scientific Results 121, 489-503.

Sparks, R. S. J., Moore, J. G., and Rice, C. J. (1986). The initial giant umbrella cloud of the May 18, 1980, explosive eruption of Mount St. Helens. Journal of Volcanology and Geothermal Research 28, 257.

Sparks, R. S. J., and Walker, G. P. L. (1977). The significance of vitricenriched airfall ashes associated with crystal-rich ignimbrites. Journal of Volcanology and Geothermal Research 2, 329.

Stothers, R. B. (1984a). Mystery cloud of AD 536. Nature 307, 344345.

Stothers, R. B. (1984b). The great Tambora eruption in 1815 and its aftermath. Science 224, 1191-1198.

Stothers, R. B., Wolff, J. A., Self, S., and Rampino, M. R. (1986). Basaltic fissure eruptions, plume heights, and atmospheric aerosols. Geophysical Research Letters 13, 725-728.

Streeter, S. S., and Shackleton, N. J. (1979). Paleocirculation of the deep North Atlantic: 150,000-year record of benthic foraminifera and oxygen-18. Science 203, 168-171.

Turco, R. P., Toon, O. B., Ackerman, T. P., Pollack, J. B., and Sagan, C. (1990). Climate and smoke: An appraisal of nuclear winter. Science $247,166-176$.

Westrich, H. R, and Gerlach, T. M. (1992). Magmatic gas source for the stratospheric $\mathrm{SO}_{2}$ cloud from the June 15, 1991, eruption of Mt. Pinatubo. Geology 20, 867-871.

Wigley, T. M. L. (1991). Climate variability on the 10-100-year time scale: Observations and possible causes. In "Global Changes of the Past" (R. S. Bradley, Ed.), pp. 83-101. UCAR/Office for Interdisciplinary Earth Studies, Boulder.

Williams, J. (1975). The influence of snowcover on the atmospheric circulation and its role in climatic change: An analysis based on results from the NCAR Global Circulation Model. Journal of Applied Meteorology 14, 137-152. 
Williams, L. D. (1979). An energy balance model of potential glacierization of northern Canada. Arctic and Alpine Research 11, 443-456.

Wilson, C. (1985). The Little Ice Age on Eastern Hudson/James Bay: The summer weather and climate at Great Whale, Port George and Eastmain, 1814 to 1821 , as derived from Hudson's Bay Company records. Syllogeus 55, 147-1990.

Woillard, G., and Mook, W. G. (1982). Carbon-14 dates of Grande Pile: Correlation of land and sea chronologies. Science 215, 159-161.
Woods, A. W. (1988). The thermodynamics and fluid dynamics of eruption columns. Bulletin Volcanologique 50, 169-191.

Woods, A. W., and Kienle, J. (in press). The dynamics and thermodynamics of volcanic clouds: Theory and observations from the April 15 and April 21, 1990 eruptions of Redoubt, Alaska. Journal of Volcanology and Geothermal Research.

Woods, A. W. M., and Wohletz, K. H. (1991). Dimensions and dynamics of co-ignimbrite eruption columns. Nature 350, 225-227. 